\title{
EGUADOR: CONSTITUTIONS AND CAUDILLOS
}





\section{EGUADOR: GONSTITUTIONS AND GAUDILLOS}

BY

GEORGE I. BLANKSTEN

UNIVERSITY OF CALIFORNIA PRESS

BERKELEY AND LOS ANGELES

$195 \mathrm{I}$ 


\section{University of California Publications in Political Science}

Editors (Los Angeles) : W. W. Crouch, R. N. Fitzgibbon, R. G. NeumanN

Volume 3, No. 1, pp. xiv + 1-196, 1 map

Submitted by editors December 7, 1949

Issued Mareh 23, 1951

Price, cloth, $\$ 3.00$; paper, $\$ 2.00$

\section{University of California Press \\ Berkeley aNd Los ANGeles \\ CALIFornia \\ $\diamond$ \\ Cambridge University Press \\ LONDON, ENGLAND}


"Ecuador is a very difficult country to govern." Jose María Velasco Ibarra 



\section{FOREWORD}

IT IS CONTENDED, quite properly, that "comparative government" ought to compare features and problems of government. A necessary prerequisite, however, is possession of knowledge about individual governments and political systems so as to make comparisons meaningful. Even before the days of Bagehot and Bryce, of Lowell and Wilson, we had a sufficient fund of information about the governmental systems of Britain and the United States to make comparisons of those two major governments useful and popular. Gradually, some of the blind spots, especially those affecting the principal governments of continental Europe and, to a lesser extent, certain of the British dominions, began to be filled in. But, until recent decades, the politics and governments of the Far, Near, and Middle East and other large areas of the world remained, in essence, almost as much of a dark continent as the government of United States counties had earlier been said to be.

One of those lacunae was, by and large, Latin America. By the end of the first quarter of the present century, almost the only serious and substantial studies of individual Latin American governmental systems in print were the three volumes published by the Carnegie Institution of Washington, written by Messrs. Rowe, James, and Stuart, and dealing respectively with Argentina, Brazil, and Peru. These volumes were the first ones in a projected series, the plan for which was later abandoned; only one other volume in that series was published. During the second decade of the century the number of books published about Mexico was legion, but with a few notable exceptions they were journalists' accounts of the turbulent polities of that turbulent decade and were not objective studies of a political system as such. The articles that have been published in magazines and newspapers about politics elsewhere in Latin America have usually been about the more newsworthy-which sometimes has seemed synonymous with "sensational"-aspects of Latin American politics.

The Latin Americans themselves have been peculiarly slow to examine carefully the anatomy and physiology of their political systems. The reason may lie in considerable part in the fact that many Latin American intellectuals tend to approach the subjects of their artention with the view of an artist rather than that of a scientist. A particular government is of interest not so much because of the details of its inner structure and operation as because of the external and complete picture which it makes. In the organization of their university curricula, the Latin 
Americans do not establish departments (or "faculties") of "political science" or "government." It is true that we encounter the terms ciencias politicas and ciencias económicas (though ciencias sociales is more common). But the use of the plural is significant: it betokens a concern with interrelationships which is rather strikingly in contrast with the increasing compartmentalization of studies in the United States.

Each of the approaches doubtless has its advantages. It remains generally true, however, that, at least for purposes of the study in this country of comparative government, we must know much more, very much more, about some of the blind spots. Professor Blanksten, in this study of Ecuador, admirably fills in these gaps with respect to the "Republic of the Equator."

It is gratifying that the author should have chosen as the subject of his analysis one of the less well-known states of Latin America. The smaller states or the more "backward" (that adjective is ungracious but sometimes not avoidable) have with one or two exceptions been little studied. But it is fully as important that we know why political Ecuador is as it is as that we have the same comprehension of Argentina or Brazil or Mexico. What is important is not the relative weight that the particular state carries internationally but rather the sort of contribution it can make to our knowledge and understanding of comparative government as a whole. Ecuador definitely makes a contribution of significance.

Professor Blanksten surveys the political scene in Ecuador penetratingly and sympathetically. He does not stop with merely a compendium of governmental and administrative data but inquires searchingly into the more obscure political forces and problems as well. His understanding of the country's political problems came not only from library study in the United States but also from extensive research in Ecuador. Nor was that research limited to Quito. It extended to other centers in the Sierra, to Guayaquil and other parts of the Coast, and even to the Oriente. The Galápagos (as the fourth more or less formal division of the country) can well be left to Dr. William Beebe and his confreres.

Easy generalization about Latin America is a sin any student of the area should avoid religiously. But to the slight extent that it would seem permissible, this study of Ecuador may be regarded as a case study of states similarly developed. First and most important, however, it gives us much the best study, of any length and in any language, of Ecuador's constitutional and political problems. For that we are in Professor Blanksten's debt.

University of California, Los Angeles

Russell H. FitzaibBon

March, 1950 


\section{PREFACE}

"WHY DID You choose Ecuador?" The question invariably has been thrust at me by friends and associates throughout my work on this volume. It is my hope that the following pages will make a twofold contribution to our understanding of problems common to much of the Latin American area.

In the first place, this book offers an interpretation of political instability in an American republic with a large Indian population. The interpretation is addressed specifically to Ecuador, but I suspect that work on that country might be of some use in inquiring into similar problems in a number of other American nations. Ecuadorans say that theirs is the "classic" country in which to study Latin American revolutions. The chronic political problems of Ecuador-revolution, caudillismo, ineffective written constitutions--plague many another HispanoAmerican state. Moreover, political instability in these countries is little understood in the United States. I do not claim that the reader will find in this book the whole answer to this problem, either in Latin America as a whole or in Ecuador particularly; but I believe it is justified if it adds a measure of insight to our search for an appreciation of some of the difficulties of a number of the other American republics.

Second, the development of a Latin American literature in political science has long been hampered by the paucity of basic information on the individual countries. Research in each of these republics must precede the emergence of a solid general literature on the political problems of this area. I hope that this volume may add something to our knowledge of Ecuador and thereby serve as a step, however small, in the accumulation of basic data necessary to the evolution of a workable literature on the area as a whole.

My especial interest in Ecuador stems from a four-year sojourn in Washington, D.C., beginning in 1942, when I was associated with the Office of the Coördinator of Inter-American Affairs and later with the Department of State. However, no country - and certainly not Ecuador-can be studied adequately from afar, and in March, 1948, I journeyed to the tiny "Republic of the Equator." During my six-month stay in Ecuador, I visited all three continental regions of the country and lived with the people and their problems. Documentary materials are abundant in the republic, and I used them liberally; but this book is not pieced together from documents. I shared the life of the Sierra Indian in some of his villages; I attended sessions of congress and of a 
number of the courts; I lived in picturesque and formal Quito and in lazy, easygoing Guayaquil; and I bounced in a jeep through a part of the fabulous Oriente. I believe I know the Ecuadoran people, and I feel a warm friendship for them. I hope that this sentiment has not mitigated the objectivity - the "irrational passion for dispassionate rationality"-which I have endeavored to preserve in the following pages.

I was aided by a number of Ecuadorans while I was in their country, and it is difficult to single out a few of them for mention here. I am particularly grateful to Aníbal and Barbara Buitrón一she is a North American-for their warm hospitality and invaluable aid on Indian questions, and to Dr. Pío Jaramillo Alvarado, the venerable dean of Ecuador's students of Indian life, for his assistance in understanding a number of social problems. Dr. Homero Viteri Lafronte and his son, Jorge Viteri de la Huerta; former Presidents Carlos Alberto Arroyo del Río and Federico Páez; and Mayor Rafael Guerrero Valenzuela of Guayaquil gave unstintingly of their time in aiding with political data. Dr. José Vicente Trujillo and Fernando Barredo Hidalgo were exceedingly helpful in the development of information and viewpoints on the judicial function; and I profited greatly from Dr. Carlos A. Rolando's knowledge of the field of administrative history. To José Coronel Robles, my "man Friday" at Guayaquil, I am exceedingly thankful.

I owe a debt of gratitude to Dr. Russell $\mathrm{H}$. Fitzgibbon of the University of California, Los Angeles, for innumerable forms of aid, not the least of which was a most helpful critical reading of the manuscript; and to Drs. Foster H. Sherwood and Robert G. Neumann, also of the University of California, Los Angeles, who likewise made valuable suggestions. Also, sections of the text were criticized by Drs. Charles S. Hyneman and Paul P. Van Riper, both of Northwestern University. I wish, further, to acknowledge the help of the Honorable John F. Simmons, the United States Ambassador at Quito, and the assistance of the Division of International Exchange of Persons, United States Department of State, which made possible my stay in Ecuador from March to September of 1948. None of these people, of course, is guilty of complicity in any errors of fact or judgment which may have erept into the book; the responsibility for them is my own.

Evanston, Illinois

March, 1950

G. I. B. 